\title{
Offshore entrainment of anchovy larvae and its implication for their survival in a frontal region of the Kuroshio
}

\author{
Yuji Okazaki1 ${ }^{1, *}$, Hideaki Nakata ${ }^{1}$, Shingo Kimura ${ }^{2}$, Akihide Kasai ${ }^{3}$ \\ ${ }^{1}$ Faculty of Fisheries, Nagasaki University, 1-14 Bunkyo-machi, Nagasaki 852-8521, Japan \\ ${ }^{2}$ Ocean Research Institute, University of Tokyo, 1-15-1 Minamidai, Nakano, Tokyo 164-8639, Japan \\ ${ }^{3}$ Graduate School of Agriculture, University of Kyoto, Kyoto 606-8502, Japan
}

\begin{abstract}
Focusing on an incidence of coastal water entrainment into the Kuroshio frontal region, we looked at the fate of anchovy larvae Engraulis japonicus originating from coastal spawning grounds and entrained into the frontal region with the coastal low salinity water. Drifters were released in the low salinity water of the Kuroshio frontal region, and observation and sampling were conducted during drifter tracking from 18 to 21 May 1997. Naupliar copepod abundance and copepod production were high in the low salinity water at an early phase of the tracking, but decreased with elapsed days. Anchovy larvae were most abundant on the coastal side of the Kuroshio, especially in the low salinity water. Their ages estimated from otoliths were consistent with those inferred from the advective transport speed from the coastal spawning ground. The estimated biological mortality rate of first-feeding larvae (less than $7 \mathrm{~d}$ old) in the low salinity water was $0.71 \mathrm{~d}^{-1}$, which was high compared to rates previously reported for Engraulis spp. This high mortality could have been caused by poor nutritional conditions due to decreasing copepod production and abundance, suggesting that the offshore entrainment of fish larvae originating from coastal water could be unfavorable for their survival. The encounter with a frontal eddy would enhance food production and the subsequent survival of anchovy larvae in the frontal region; otherwise, they may perish due to low food availability.
\end{abstract}

KEY WORDS: Anchovy larvae - Offshore entrainment $\cdot$ Kuroshio front $\cdot$ Larval survival

\section{INTRODUCTION}

Larval transport from spawning to nursery areas is a major factor inducing variability in the larval survival and subsequent recruitment to marine fish populations (Hjørt 1914, Norcross \& Shaw 1984). Along the Pacific coast of Japan, most of the pelagic fishes, such as anchovy, sardine and mackerel, spawn in the Kuroshio Current and its coastal water (National Research Institute of Fisheries Science 1995). Since the larval food availability in the offshore Kuroshio water is appreciably low compared to the coastal water (Nakata et al. 1995), interaction between the Kuroshio and its coastal water could be critical to the larval survival for those coastal spawners.
Coastal water is often entrained into the Kuroshio frontal region (Fig. 1), which possibly results in the aggregation of coastal planktonic organisms in the Kuroshio front (Yamamoto et al. 1988, Nakata 1990, Kidachi 1997). Further, cyclonic eddies caused by frontal disturbances of the Kuroshio could enhance primary production and larval prey production in the frontal region (Kimura et al. 1997, Nakata et al. 2000). The plankton aggregation and production enhancement in the frontal region could provide favorable feeding conditions for larval fish in the offshore region. However, the influence of the offshore entrainment of fish larvae originating from the coastal spawning grounds has not yet been fully clarified in the Kuroshio front. 
In addition, it has been reported that larval and juvenile anchovy are broadly distributed to the far east of the Japanese coast, corresponding to a recent increase in the Japanese anchovy stock (Takahashi et al. 2001). This suggests that the larval survival in the offshore water could be of importance, particularly to the anchovy in the Kuroshio region in recent years.

The objectives of this study are to quantify the time changes in the abundance and food availability of anchovy larvae being entrained from the coastal water to the Kuroshio front, and to examine the effect of the interaction between the Kuroshio and its coastal water on larval survival. In this context, we focused on an incidence of coastal water entrainment into the Kuroshio frontal region off the Enshu-nada Sea, one of the major spawning grounds of Japanese anchovy off the Pacific coast of Japan (Funakoshi et al. 1984). The main spawning period of the anchovy in the Enshu-nada Sea is from spring to autumn; the peak frequently occurs in spring (Funakoshi 1990).

The ocean color image (ADEOS/OCTS) of the study area taken on 18 May 1997 is shown in Fig. 1, and demonstrates that coastal water was entrained into the Kuroshio front. Taking this opportunity, we released drifters in the coastal water and sampled larval anchovy along the drifter track from 18 to 21 May 1997, when the drifter moved through the Kuroshio frontal region. During the drifter tracking period, we investigated the time change in the distribution and abundance of anchovy Engraulis japonicus larvae and their prey organisms. The nutritional condition, growth and mortality of the anchovy larvae were also estimated.

\section{MATERIALS AND METHODS}

Observations of the Kuroshio front off the central Pacific coast of Japan were made from RV 'Hakuho-Maru' from 18 to 22 May 1997. Four drifters were released in the coastal water marked by low salinity, and tracked from 16:10 h on 18 May, to $06: 21$ h on 21 May, for 46 to $54 \mathrm{~h}$. The drifters were composed of a surface buoy and a $2 \times 5 \mathrm{~m}$ drogue centered at a depth of $18 \mathrm{~m}$ below the sea surface. The drifter's position was monitored using the ship's radar linked to a global positioning satellite system (GPS). Following the drifters, physical and biological surveys were conducted at night along 3 transects (Fig. 2; Line 1, Stns D1 to D6; Line 2, Stns D13 to D18; Line 3, Stns D25 to D28). The drifters were retrieved after the Day 2 survey (Line 3). A fourth transect (Line 4, Stns D29 to D34) was conducted along the same longitudinal section as Line 3 to describe detailed physical and biological structure on a wider spatial scale. Along each transect, temperature and salinity were measured by a Seabird CTD (Seabird Electronics) deployed to $500 \mathrm{~m}$ depth. The CTD data were depth-averaged into $1 \mathrm{~m}$ depth strata. Larvae were collected using the Ocean Research Institute (ORI) net with $1.6 \mathrm{~m}$ diameter and $0.33 \mathrm{~mm}$ mesh size (Omori 1965). The ORI net was fitted with a flowmeter to estimate the volume filtered and towed for 3 to $5 \mathrm{~min}$ at a speed of $1 \mathrm{~m} \mathrm{~s}^{-1}$. The larval sampling was conducted in the surface layer (ca. upper $2 \mathrm{~m}$ depth), where most of anchovy larvae were found in the Kuroshio and its coastal area at night (Nakata et al. 2000). Larval abundance was standardized to number of individuals under $1000 \mathrm{~m}^{3}$. Up to 40 individuals of the anchovy larvae in the sample were

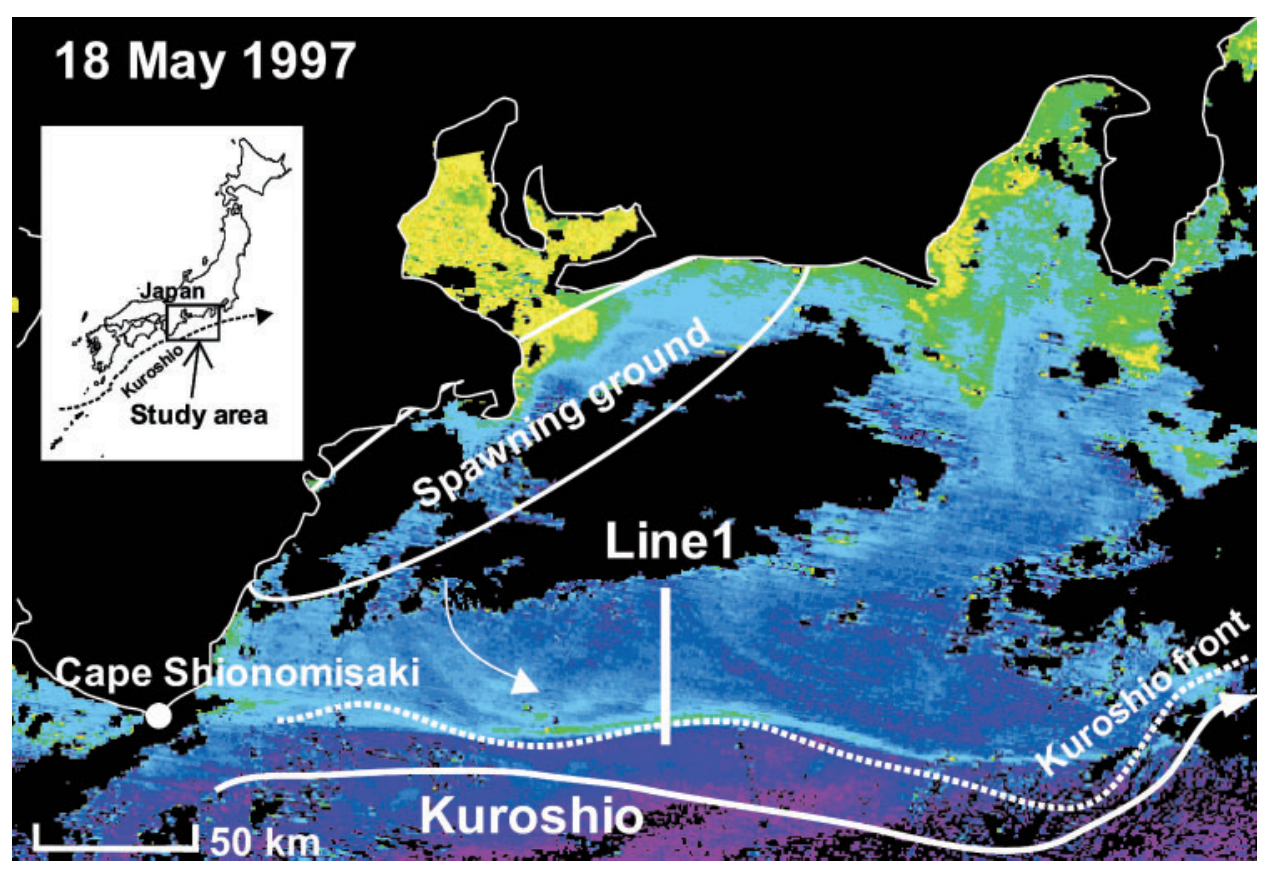

Fig. 1. Satellite ocean color images in the Enshu-nada Sea taken by Midori on 18 May 1997. Location one of the survey transects (Line 1) and the coastal spawning ground of anchovy in this region are shown. Dashed line indicates the position of the Kuroshio front inferred from the satellite SST image. Black areas indicate land or cloud 


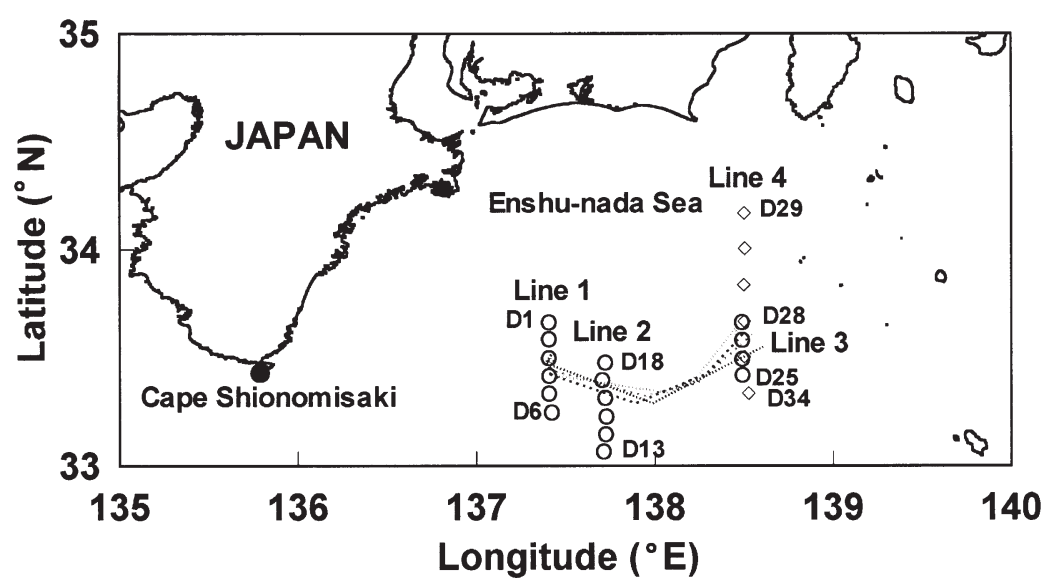

Fig. 2. Transects (Lines 1 to 4 ) and stations (Stns D1 to D34) for the CTD observation and the collection of fish larvae and their prey organisms across the Kuroshio front in the Enshu-nada Sea from 18 to 22 May 1997. Dashed lines indicate drifter trajectories

immediately sorted on the ship for the analyses of nucleic acid content and otoliths, then the larvae were stored in sucrose solution $(0.25 \mathrm{M}$ sucrose, $1 \mathrm{mM}$ EDTA, $20 \mathrm{mM}$ Tris-HCL, $\mathrm{pH} 7.5$ ) at $-80^{\circ} \mathrm{C}$ until the analyses were conducted. A small portion of zooplankton collected with the ORI net was stored on the fine mesh gauze at $-80^{\circ} \mathrm{C}$ for the nucleic acid analysis of adult female copepods. The remains of larval and plankton samples were preserved in $2.5 \%$ seawater glutaraldehyde. Larval prey (mainly naupliar copepods) were collected from the surface water $(0$ to $0.3 \mathrm{~m})$ using a bucket simultaneously with the ORI net deployment, since naupliar copepods were most abundant in the surface layer in the Kuroshio and its coastal water (Okazaki et al. 2002). The larval prey samples (1 l) were fixed in $5 \%$ seawater formalin after concentration by a plankton net with $0.020 \mathrm{~mm}$ mesh. Nutrient and $\mathrm{chl} a$ concentrations of the water samples were also determined and reported by Kasai et al. (2002). The total number of net tows and larval prey samplings were 18 and 20, respectively. The sampling was conducted once at each station due to time constraints, because all samplings along one transect had to be completed during the night to reduce potential bias associated with net avoidance by the larvae.

In the laboratory, fish larvae were sorted from the preserved samples. The standard length (SL) of anchovy larvae, the most dominant species, was measured, and naupliar copepods in the water samples were counted without identifying species.

We use Paracalanus sp. for nucleic acid analysis of female copepods. This species is one of the dominant copepods in the Kuroshio frontal region (Hirota 1995). The quantities of DNA and RNA in the individual anchovy larva and 10 adult female Paracalanus sp. from each station were determined by the fluorescence technique described by Clemmesen (1993) and further modified by Sato et al. (1995). Specimens were homogenized in $0.4 \mathrm{ml}$ of Tris-SDS buffer $(0.05 \mathrm{M}$ Tris, $0.1 \mathrm{M} \mathrm{NaCl}, 0.01 \mathrm{M}$ EDTA, 2\% SDS, $\mathrm{pH}$ 8.0) containing Proteinase K (0.2 mg $\mathrm{ml}^{-1}$ ) using a shaking mill for $1 \mathrm{~h}$, and fluorescence-photometric measurements were subsequently made using ethidium bromide (EB). In total, 164 individual anchovy larvae and 15 samples of Paracalanus sp. were analyzed for their RNA:DNA ratios.

For the otolith processing method we followed Watanabe \& Kuroki (1997). Prior to otolith extraction, the standard length of each larval anchovy was measured to the nearest $0.1 \mathrm{~mm}$. Sagittal otoliths were dissected out and mounted on a glass slide with enamel resin. A total of 123 otoliths were examined. We counted the total number of daily growth rings and measured the radius of each ring using an otolith measurement system (RATOC System Engineering) consisting of a light microscope, a CCD camera, video monitor and an image analyzer controlled by a computer. We determined allometric parameters for each fish by using the biological intercept method (Campana 1990). The SL of anchovy at the first ring deposition was fixed at $4 \mathrm{~mm}$ for the biological intercept, referring to Takita (1988). Tsuji \& Aoyama (1984) verified the daily deposition of otolith growth rings in Japanese anchovy after the 3rd to 4 th day from hatching when larvae start feeding. Therefore, daily age of each anchovy larva was calculated as the number of rings plus 3 .

The mortality rate $(Z)$ during the drifter tracking was estimated for anchovy larvae below $20 \mathrm{~d}$ of age as:

$$
Z=\frac{\ln \left(C_{t_{1}}\right)-\ln \left(C_{t_{2}}\right)}{t_{2}-t_{1}}
$$

where $\mathrm{C}_{t_{1}}$ is the density of the cohort at time $1\left(t_{1}\right), \mathrm{C}_{t_{2}}$ is the density of the same cohort at time $2\left(t_{2}\right)$. The larval cohorts were divided into 2 groups: first-feeding larvae and post first-feeding larvae (hereafter post larvae). The mortality rate was estimated for each group, based on the data from the first transect (Line 1, Fig. 1) at Day 0 and the third transect (Line 3, Fig. 1) at Day 2, taking the larval growth from Day 0 to Day 2 into account. The age range of the first-feeding larvae at Day 0 was less than $5 \mathrm{~d}$ old and that of the post larvae was 6 to $18 \mathrm{~d}$ old.

We further defined the high salinity water associated with the Kuroshio (psu > 34.55, referred to hereafter as 'the Kuroshio water'), moderate salinity water $(34.35<$ psu $<34.55$ ) and low salinity water (psu < 34.35), referring to Kasai et al. (2002). 

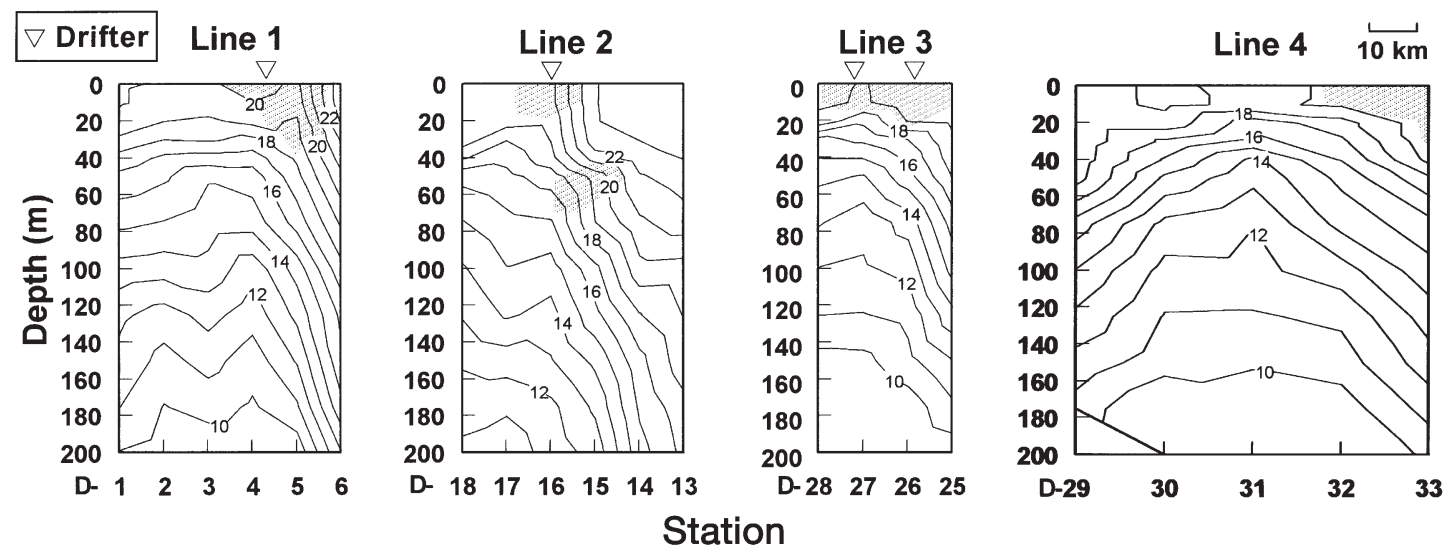

Fig. 3. Vertical profiles of temperature, together with distribution of low salinity water (indicated by the shaded area) across the Kuroshio front measured along transects (Lines 1 to 4; Stns D1 to D6, D13 to D18, D25 to D28 and D29 to D33, respectively) in

the Enshu-nada Sea from 18 to 22 May 1997. Open triangles denote the drifter position. Note: no CDT observations for Stn 34

\section{RESULTS}

\section{Cross-frontal distributions of physical and biological properties}

Large horizontal temperature gradients between the Kuroshio and coastal water were detected along Lines 1 and 2, indicating the location of the Kuroshio front (Fig. 3). It is noteworthy that the low salinity water existed at the northern edge of the front. The position of the drifter coincided well with that of the low salinity water for each transect, indicating that the drifter represented the horizontal movement of the low salinity water. The average speed of the drifters moving toward the east was about $0.56 \mathrm{~m} \mathrm{~s}^{-1}$.

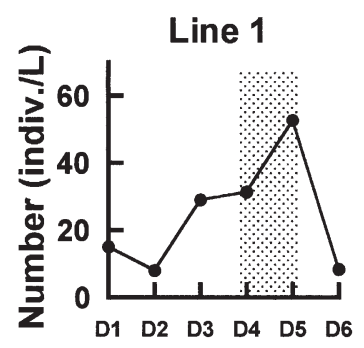

Line 2
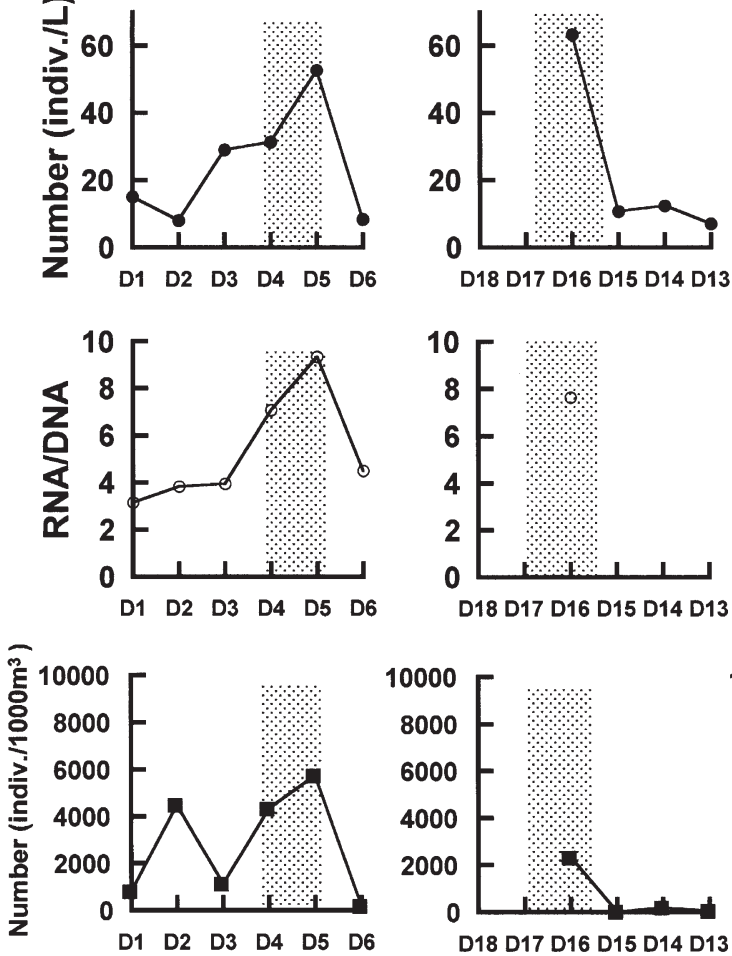

Line 3
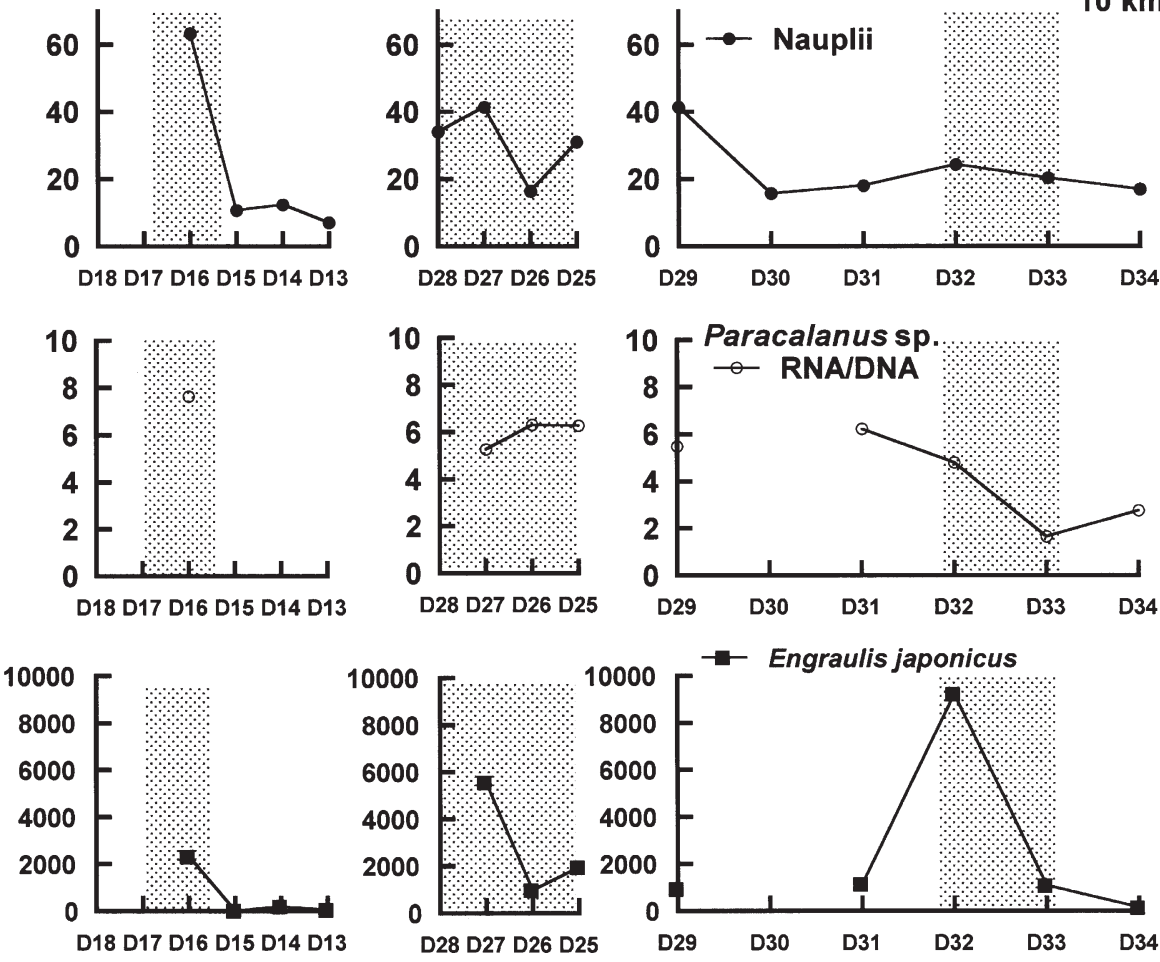

Line 4
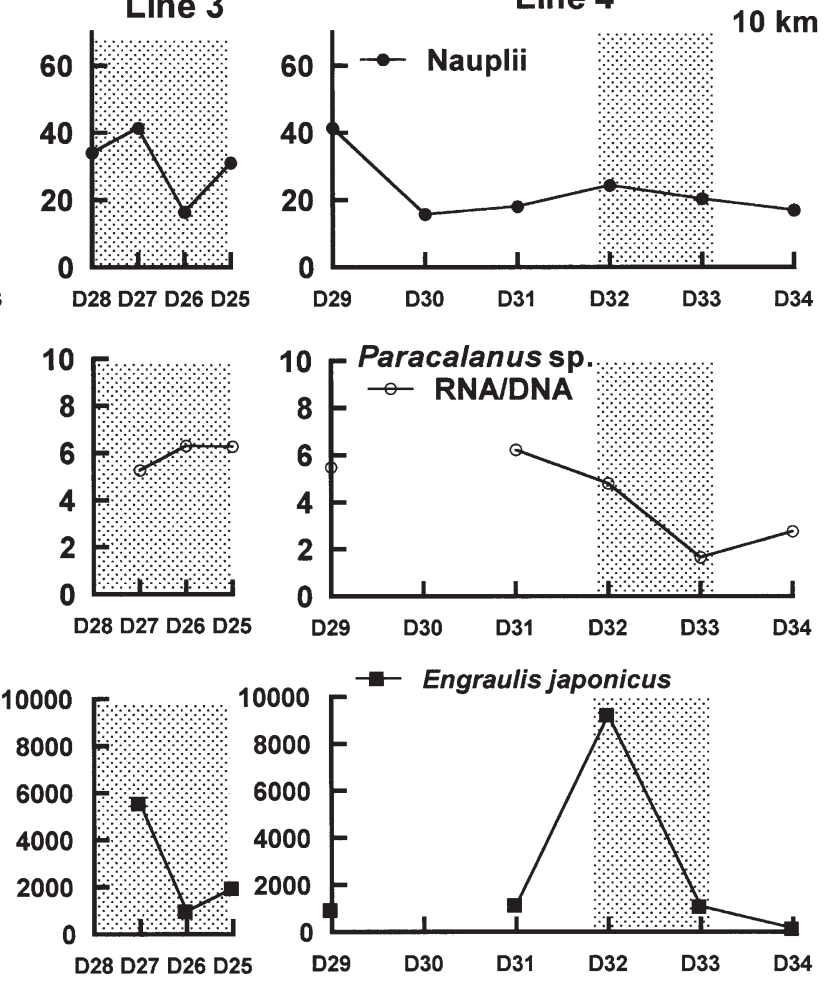

\section{Station}

Fig. 4. Distributions of naupliar copepod abundance, RNA:DNA ratios of female Paracalanus sp. and abundance of anchovy larvae across the Kuroshio front measured along transects (Lines 1 to 4; Stns D1 to D6, D13 to D18, D25 to D28 and D29 to D34, respectively) in the Enshu-nada Sea from 18 to 22 May 1997. Shaded areas denote the low salinity water 
The $14^{\circ} \mathrm{C}$ isotherm decreased in depth from $80 \mathrm{~m}$ (Line 1) to $50 \mathrm{~m}$ (Line 3) during the tracking, and a marked dome-shape isotherm distribution was found along Line 4 ; this suggests that a marked upwelling induced by a frontal eddy occurred in the latter transects (Lines 3 to 4), and that the low salinity water could be entrained from the Kuroshio front to the edge of the frontal eddy by its cyclonic motion.

Naupliar abundance was appreciably higher in the low salinity water along Lines 1 and 2; however, it decreased in the latter transects where the differences in the abundance were not clear between the low salinity water and the surrounding water (Fig. 4). The RNA:DNA ratios of female Paracalanus sp. showed a marked peak in the low salinity water along Line 1, indicating that copepod egg production was high in the low salinity water (Nakata et al. 1994, Saiz et al. 1998). However, the RNA:DNA ratios decreased with time, corresponding to the temporal decline in the naupliar abundance.

Anchovy larvae were most abundant on the coastal side of the Kuroshio, especially in the low salinity water, and rapidly decreased in the Kuroshio water (Fig. 4). Since the low salinity water in the Kuroshio frontal region originated from the coastal region, as inferred from the ocean color image taken during the survey period (Fig. 1), the anchovy larvae that collected in the low salinity water could have been entrained from the coastal spawning ground.

\section{Nutritional condition and growth of larvae}

Positive correlations were found between naupliar abundance and mean RNA:DNA ratios of anchovy larvae for 3 larval size classes (Fig. 5). The correlations were significant $(p<0.05)$ for $7-8 \mathrm{~mm}$ and $8-9 \mathrm{~mm}$ classes.

Mean back-calculated SLs of the larvae collected from the low salinity water linearly increased with age, and could be expressed by a simple liner regression; $y=0.63 x+1.97\left(r^{2}=0.995\right)$. Furthermore, the recent growth rate was calculated from the 3 outer otolith increment widths for each larva in the low salinity water. The mean recent growth rate $( \pm \mathrm{SD})$ was $0.57 \pm$ $0.16 \mathrm{~mm} \mathrm{~d}^{-1}(\mathrm{n}=123)$.

Fig. 6 shows the mean density of anchovy larvae in each length category (standard length) in the low salinity water at Stns D4 and D5 on Day 0 and Stns D25, D26 and D27 on Day 2. The mean length of the anchovy larvae increased from Day 0 to Day 2. Assuming that the SL of first-feeding anchovy larvae was $4 \mathrm{~mm}$ (Takita 1988), and the period of egg development was $1.7 \mathrm{~d}$ at a temperature of $20^{\circ} \mathrm{C}$ (Azeta 1981), then the time elapsed since spawning was estimated to be 4 to

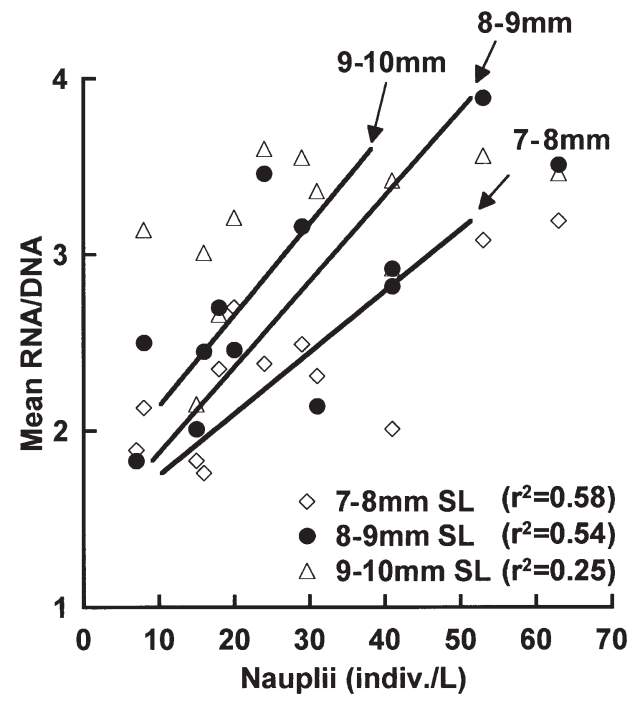

Fig. 5. Relationship between naupliar copepod abundance and mean RNA:DNA ratios of anchovy larvae for 3 size classes, measured from 18 to 22 May 1997. The mean RNA:DNA of each station was based on the data from individual larvae (1-16 ind.)

$25 \mathrm{~d}$, with a mean of $8.5 \mathrm{~d}$ for the size frequency distribution of anchovy larvae at Day 0 .

\section{Larval mortality estimate}

Larval age distributions in the low salinity water at Days 0 and 2 were obtained from the relationship between larval length and age, as described above, and the length-frequency distribution (Fig. 6). The densities of first-feeding larvae and post larvae at Day 0 (Stns D4 and D5) and Day 2 (Stns D25, D26, and D27) are shown in Table 1, together with the apparent daily mortality rates for the first feeding larvae $\left(0.96 \mathrm{~d}^{-1}\right)$ and for the post larvae $\left(0.18 \mathrm{~d}^{-1}\right)$. The larval survival during these $2 \mathrm{~d}$ were 14.5 and $70.2 \%$, respectively.

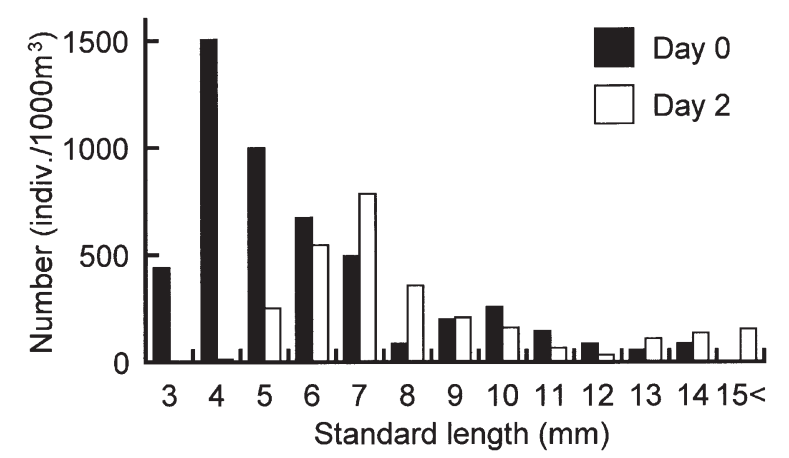

Fig. 6. Length frequency distributions of anchovy larvae collected from Stns D4 and D5 on Day 0 and Stns D25, D26 and D27 on Day 2 in the low salinity water 
Table 1. Mean density of the first feeding larvae (less than $5 \mathrm{~d}$ old at Day 0 sampling) and the post larvae ( 6 to $<18 \mathrm{~d}$ old) in the low salinity water. Apparent mortality rate $(Z)$ and survival rate (during 2 d) of each age cohort are also demonstrated. Day 0 and Day 2 samplings include Stns D4 and D5 and Stns D25, D26 and D27, respectively

\begin{tabular}{|c|c|c|c|c|}
\hline \multirow{2}{*}{$\begin{array}{l}\text { Age cohort (d) } \\
\text { at Day 0 } \\
\text { sampling }\end{array}$} & \multicolumn{4}{|c|}{ Larval densities (ind. $1000 \mathrm{~m}^{-3}$ ) } \\
\hline & $\begin{array}{c}\text { Day 0 } \\
\text { sampling }\end{array}$ & $\begin{array}{c}\text { Day } 2 \\
\text { sampling }\end{array}$ & $\begin{array}{c}Z \\
\left(\mathrm{~d}^{-1}\right)\end{array}$ & $\begin{array}{l}\text { Survival } \\
\text { rate }(\%)\end{array}$ \\
\hline$<5$ & 1810.0 & 263.3 & 0.96 & 14.5 \\
\hline $6-18$ & 3066.9 & 2153.6 & 0.18 & 70.2 \\
\hline
\end{tabular}

The mortality rate estimated above could be biased by diffusion during the drifter tracking period. Assuming that time change in the width of low salinity water on the transects from Day 0 (about $15 \mathrm{~km}$ ) to Day 2 (about $25 \mathrm{~km}$ ) was mainly due to the diffusion in the cross-frontal direction, the diffusive loss due to this cross-frontal diffusion was approximately $40 \%$ per $2 \mathrm{~d}$. Therefore, after correcting for the diffusive loss in the larval density decline, the net (biological) mortality rates for the first-feeding larvae and for the post larvae were estimated to be 0.71 and $-0.08 \mathrm{~d}^{-1}$, respectively.

Further, the RNA:DNA ratios of anchovy larvae in the low salinity water at Day 0 were compared with those of Day 2. As shown in Fig. 7, a significant decline in the larval RNA:DNA ratio was detected between Day 0 and Day 2 (ANCOVA, p < 0.01). This indicates that the larval nutritional condition at Day 2 was degraded from that at Day 0.

\section{DISCUSSION}

Larvae originating from coastal water have been collected in the Kuroshio front (Hattori 1970, Kuroda

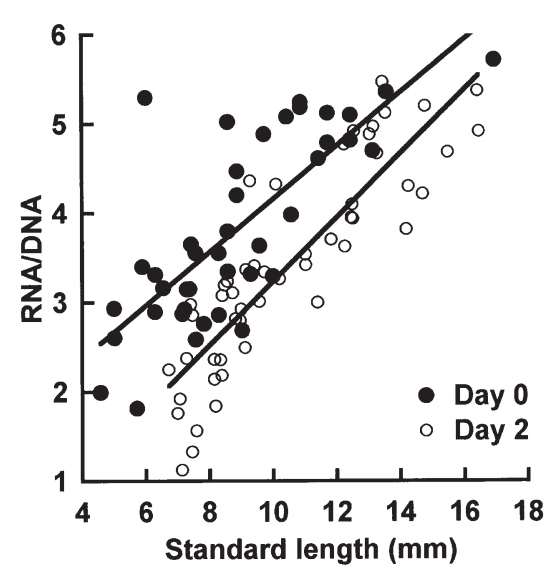

Fig. 7. Scattergrams and least squares regressions of standard length (SL) and RNA:DNA ratios for anchovy larvae in the low salinity water on Days 0 and 2
1986), suggesting that entrainment of coastal larvae frequently occurs in the Kuroshio region. The low salinity water discharged from estuaries along the coast moves through the coastal region of the Kuroshio with a speed of about 5 to $10 \mathrm{~cm} \mathrm{~s}^{-1}$ (Imasato \& Qio 1987). Assuming that the distance from the coast to the Kuroshio front was 50 to $100 \mathrm{~km}$, the low salinity water could take 6 to $23 \mathrm{~d}$ to get to the Kuroshio front, which is consistent with the age range (4 to $25 \mathrm{~d}$ old) estimated for the anchovy larvae collected in the low salinity water. Therefore, these anchovy larvae were likely transported together with coastal water from their spawning grounds to the Kuroshio frontal region.

Although high naupliar abundance and copepod RNA:DNA ratios were obtained in the low salinity water at Day 0, both decreased in the subsequent transects (Lines 3 and 4). According to Kasai et al. (2002), nutrients were already depleted in the low salinity water at Day 0, suggesting that primary productivity rapidly declined in the surface water. This could lower secondary production. Furthermore, the RNA:DNA ratios of the anchovy larvae in the low salinity water also decreased in the latter transects. The significant positive correlation between RNA:DNA ratios of anchovy larvae and naupliar abundance was consistent with several other recent studies, e.g. Canino et al. (1991), Bailey et al. (1995) and Chícharo et al. (1998). The results of our study mentioned above indicate that biological production in the Kuroshio frontal region could not be sustained or accelerated by the coastal water entrainment. Instead, the frontal eddy, as was shown in Lines 3 and 4, may play an important role in the biological production and larval survival in the Kuroshio frontal region.

Although there has been no information on the mortality rate of Japanese anchovy larvae in the Kuroshio region, that of northern anchovy larvae in the California Current region was reported to range from 0.13 to $0.23 \mathrm{~d}^{-1}$, over a period of yolk-sac absorption through to ca. 25 to $30 \mathrm{~d}$ old (Hewitt \& Methot 1982). In the southern Brazilian Bight, the mortality rate of larval anchovy was $0.064 \mathrm{~d}^{-1}$ from 15 to $35 \mathrm{~d}$ (Kitahara \& Matsuura 1995). Castro \& Hernandez (2000) reported the mortality rates of the Peruvian anchovy Engraulis ringens off central Chile to be 0.05 and $0.07 \mathrm{~d}^{-1}$ for the first $35 \mathrm{~d}$. Our estimate of the biological mortality rate $\left(0.71 \mathrm{~d}^{-1}\right)$ of first-feeding larvae is appreciably high compared to the mortality rates reported previously for Engraulis spp. The mortality rate of post larvae, after correcting for diffusive loss, was negative, suggesting that it could be distorted by the immigration of larger larvae from the outside and that the biological mortality must be much smaller than that of the first-feeding larvae. In general, mortality of marine fish is a size- 
specific phenomenon (McGurk 1986, Houde 1997); thus relatively small larvae (less than $7 \mathrm{~mm} \mathrm{SL}$ ) have higher mortality rates. Kitahara \& Matsuura (1995) reported that the mortality rate of southwest Atlantic anchovy larvae smaller than $12 \mathrm{~mm}$ SL was higher than the rate of larger larvae. Mitani (1990) demonstrated that Japanese anchovy larvae up to $8 \mathrm{~mm}$ total length after hatching have no fin-lay, and therefore poor ability of swimming. Hence, first-feeding stage of anchovy larvae were more vulnerable to starvation or predation.

Along the last transect, anchovy larvae were most abundant in the outer edge of a frontal eddy in association with the entrainment of the low salinity water into the eddy (Fig. 4). Bakun (1996) mentioned that as cyclonic curvature develops, divergence and upwelling occur on the concave side of the eddy, while convergence occurs on the convex side. This convergence of the surface water may have implications for the larval aggregation on the eddy edge. The frontal eddy could have a function of enhancing primary production due to upwelling (Lee et al. 1981, Shiomoto \& Matsumura 1992, Kimura et al. 1997, 2000). Nakata et al. (2000) further indicated that naupliar copepod abundance in the frontal eddy approximately doubled in $2 \mathrm{~d}$, indicating that the encounter with the frontal eddy could improve larval feeding conditions.

In conclusion, declines in the copepod RNA:DNA ratio, naupliar abundance, and the RNA:DNA ratio of anchovy larvae in the low salinity water indicate that food availability of anchovy larvae gradually decreased in the water entrained into the Kuroshio front. The most probable reason for larval abundance decline during the drifter tracking, especially for firstfeeding stage larvae, could be poor nutritional condition or starvation due to low prey abundance. This result suggests that the offshore entrainment of fish larvae originating from coastal water could be unfavorable for their survival. The encounter with a frontal eddy would enhance the food production and the subsequent survival of anchovy larvae in the frontal region; otherwise they may perish due to low food availability.

Acknowledgements. We express our sincere thanks to the officers and crews of RV 'Hakuho-Maru' for their help with the field observation. We thank Prof. Y. Watanabe and Dr. K. Nakata for their assistance with the otolith analysis and RNA:DNA determination, respectively. Thanks are also due to the anonymous reviewers for their valuable comments, and Mr. H. Nagae and graduate students of the Fisheries Oceanography Division of the Ocean Research Institute, University of Tokyo, for assistance during the cruise. Y.O. was supported by Research Fellowships of the Japanese Society for the Promotion of Science for Young Scientists.

\section{LITERATURE CITED}

Azeta M (1981) Some considerations on the high mortality during the larval stage of fish with special reference to the fluctuation of population. Based on the population dynamics investigations of early life history of anchovy. Report from the Conference of the Fisheries Agency for the Japanese Government Fisheries Resources Investigation. Secretariate of the Fisheries Resources Investigations, Vol 22. by the Scientists of the Fisheries Agency, Japanese Government, Kohchi, p 7-28 (in Japanese)

Bakun A (1996) Patterns in the ocean. California Sea Grant College System, San Diego, CA

Bailey KM, Canino MF, Napp JM, Spring SM, Brown AL (1995) Contrasting year of prey levels, feeding conditions and mortality of larval walleye pollock Theragra chalcogramma in the western Gulf of Alaska. Mar Ecol Prog Ser 119:11-23

Campana SE (1990) How reliable are growth back-calculations based on otolith? Can J Fish Aquat Sci 47:2219-2227

Canino MF, Bailey KM, Incze LS (1991) Temporal and geographic differences in feeding and nutritional condition of walleye pollock larvae Theragra chalcogramma in Shelikof Strait, Gulf of Alaska. Mar Ecol Prog Ser 79:27-35

Castro LR, Hernandez EH (2000) Early life survival of the anchoveta Engraulis ringens off central Chile during the 1995 and 1996 winter spawning seasons. Trans Am Fish Soc 129:1107-1117

Chícharo MA, Chicharo L, Valdés L, López-jamar E, Ré P (1998) Estimation of starvation and diel variation of the RNA:DNA ratios in field-caught Sardina pilchardus larvae off the north of Spain. Mar Ecol Prog Ser 164:273-283

Clemmesen C (1993) Improvements in the fluorimetric determination of the RNA and DNA content of individual marine fish larvae. Mar Ecol Prog Ser 100:177-183

Funakoshi S (1990) Studies on the reproduction mechanisms of Japanese anchovy Engrauris japonicus (HOUTTUYN) in Enshu Nada, Ise and Mikawa Bay. Bull Aichi Fish Res Inst 10:1-208 (in Japanese with English abstract)

Funakoshi S, Muranaka F, Ikeda T (1984) Food and survival of the early postlarvae of the Japanese anchovy, Engraulis japonica (HOUTTUYN) - 1. Distribution of copepod nauplii in waters along the Pacific Coast of central Honshu. Bull Jpn Soc Fish Oceanogr 44:76-86 (in Japanese)

Hattori S (1970) Preliminary note on the structure of the Kuroshio from the biological point of view, with special reference to pelagic fish larvae. In: Stommel H, Yoshida K (eds) The Kuroshio. East-West Center Press, Honolulu, HI, p 399-404

Hewitt RP, Methot RD (1982) Distribution and mortality of northern anchovy larvae in 1978 and 1979. CalCOFI Rep 23:226-245

Hirota Y (1995) The Kuroshio, Part III. Zooplankton. Oceanogr Mar Biol Annu Rev 33:151-220

Hjørt J (1914) Fluctuations in the great fisheries of northern Europe viewed in the light of biological research. Rapp P-V Réun Cons Int Explor Mer 20:1-229

Houde ED (1997) Patterns and trends in larval-stage growth and mortality of teleost fish. J Fish Biol 51 (Suppl A):52-83

Imasato N, Qio B (1987) An event in water exchange between continental shelf and the Kuroshio off southern Japan: lagrangian tracking of a low salinity water mass on the Kuroshio. J Phys Oceanogr 17:953-968

Kasai A, Kimura S, Nakata H, Okazaki Y (2002) Entrainment of coastal water into a frontal eddy of the Kuroshio and its biological significance. J Mar Syst 37:185-198

Kidachi T (1997) Distribution ecology of macrozooplankton in 
the Kuroshio and its adjacent waters off Honshu, mainland of Japan. PhD thesis, University of Tokyo (in Japanese)

Kimura S, Kasai A, Nakata H, Sugimoto T, Simpson JH, Cheok JVS (1997) Biological productivity of meso-scale eddies caused by frontal disturbances in the Kuroshio. ICES J Mar Sci 54:179-192

Kimura S, Nakata H, Okazaki Y (2000) Biological production in meso-scale eddies caused by frontal disturbances of the Kuroshio Extension. ICES J Mar Sci 57:133-142

Kitahara EM, Matsuura Y (1995) Growth and mortality estimate of the southwest Atlantic anchovy Engraulis anchoita larva from Cape Santa Marta Grande in southern Brazil. Arch Fish Mar Res 42:251-262

Kuroda K (1986) Distribution properties of ichthyoplankton, especially the Japanese sardine and the Pacific mackerel eggs and larvae near the Kuroshio front south of Cape Shionomisaki, southern Japan. Bull Tokai Reg Fish Res Lab 119:109-122 (in Japanese)

Lee TN, Atkinson L, Legeckis R (1981) Observations of a Gulf Stream frontal eddy on the Georgia continental shelf, April 1977. Deep-Sea Res 28:347-378

McGurk MD (1986) Natural mortality of marine pelagic fish eggs and larvae: role of spatial patchness. Mar Ecol Prog Ser 34:227-242

Mitani I (1990) The biological studies on the larvae of Japanese anchovy, Engraulis japonica Hottuyn, in Sagami Bay. Spec Rep Kanagawa Prefectural Fish Exp Stn 5:1-140 (in Japanese with English abstract)

Nakata K (1990) Abundance of nauplii and protein synthesis activity of adult female copepods in the Kuroshio front during the Japanese sardine spawning season. J Oceanogr Soc Jpn 46:219-229

Nakata K, Nakano H, Kikuchi H (1994) Relationship between egg productivity and RNA:DNA ratio in Paracalanus sp. in the frontal waters of the Kuroshio. Mar Biol 119:951-596

Nakata K, Zenitani H, Inagake D (1995) Differences in food availability for Japanese sardine larvae between the frontal region and the waters on the offshore side of Kuroshio. Fish Oceanogr 4:68-79

Nakata H, Kimura S, Okazaki Y, Kasai A (2000) Implications of meso-scale eddies caused by frontal disturbance of the

Editorial responsibility: Otto Kinne (Editor),

Oldendorf/Luhe, Germany
Kuroshio Current for anchovy recruitment. ICES J Mar Sci 57:143-152

National Research Institute of Fisheries Science (1995) Distribution of eggs and larvae of pelagic fish species around Japan. National Research Institute, Fisheries Agency Resources Management Research Report Series A-1, Yokohama

Norcross BL, Shaw RF (1984) Oceanic and estuarine transport of fish eggs and larvae: a review. Trans Am Fish Sci 113: $153-165$

Okazaki Y, Nakata H, Kimura S (2002) The effects of frontal eddies on the distribution and food availability of anchovy larvae in the Kuroshio Extension. Mar Freshw Res 53: 403-410

Omori M (1965) A 160-cm opening-closing plankton net-I. Description of gear. J Oceanogr Soc Jpn 21:20-28

Saiz E, Calbet A, Fara A, Berdalet E (1998) RNA content of copepods as a tool for determining adult growth rates in the field. Limnol Oceanogr 43:465-470

Sato C, Kimura R, Nakata K, Umeda S, Suzuki M (1995) RNA/DNA ratio of first-feeding larvae of Japanese sardine. Fish Sci 61:538-539

Shiomoto A, Matsumura S (1992) Primary productivity in a cold water mass and the neighborhood area occurring off Enshunada in the late summer of 1989. J Oceanogr 48:105-115

Takahashi M, Watanabe Y, Kinoshita T, Watanabe, C (2001) Growth of larval and early juvenile Japanese anchovy, Engraulis japonicus, in the Kuroshio-Oyashio transition region. Fish Oceanogr 10:235-247

Takita T (1988) Engraulididae. In: Okiyama M (ed) An atlas of the early stages fishes in Japan. Tokai University Press, Tokyo, p 9 (in Japanese)

Tsuji S, Aoyama T (1984) Daily growth increments in otoliths of Japanese anchovy larvae, Engraulis japonica. Bull Jpn Soc Sci Fish 50:1105-1108

Yamamoto T, Nishizawa S, Taniguchi A (1988) Formation and retention mechanisms of phytoplankton peak abundance in the Kuroshio front. J Plankton Res 10:1113-1130

Watanabe Y, Kuroki T (1997) Asymptotic growth trajectories of larval sardine (Sardinops melanostictus) in the coastal waters off western Japan. Mar Biol 127:369-378

Submitted: February 11, 2002; Accepted: September 17, 2002 Proofs received from author(s): February 4, 2003 